\title{
Public Appeal to the Muhammadiyah Elementary School in Purworejo, Indonesia
}

\author{
Arum Ratnaningsih ${ }^{1}$, Dedi Runanto ${ }^{2}$, Nurhidayati $^{3}$ \\ \{arumratna@umpwr.ac.id ${ }^{1}$ \} \\ FKIP, Muhammadiyah University of Purworejo, Indonesia ${ }^{1,3}$ \\ Economy, Muhammadiyah University of Purworejo, Indonesia ${ }^{2}$
}

\begin{abstract}
This research is motivated by the phenomenon of the low attractiveness of the community in Purworejo district to send their children to Muhammadiyah elementary schools as a result of competition with low-cost public elementary schools. This study aims to analyze the marketing strategies of Muhammadiyah Elementary Schools in attracting public interest related to the attractiveness of students' parents in sending their children to SD Muhammadiyah. This research uses a qualitative type with a survey method. The survey was conducted on parents of students who send their children to Muhammadiyah elementary schools in Purworejo district. The results of this study include the first product has a positive effect on purchasing decisions. Second, price has a positive effect on purchasing decisions. Third, promotion has no effect on purchasing decisions. Fourth, place has no effect on purchasing decisions. Marketing mix has an effect on purchasing decisions. The combination of all the school's abilities in providing good educational products, affordable costs, good promotions and a comfortable place will make parents send their children to Muhammadiyah primary schools.
\end{abstract}

Keywords: Muhammadiyah elementary school, Purworejo regency

\section{Introduction}

The Muhammadiyah primary school level in Purworejo was first established in 1969 under the name Purworejo Muhammadiyah elementary school. The number of Muhammadiyah elementary schools to date has reached 8 units spread across Purworejo, Bayan, Kutoarjo, Kemiri, Purwodadi, Krendetan, and Bruno sub-districts. Muhammadiyah elementary schools that are within the scope of the primary and secondary education assemblies in Purworejo district have mostly experienced a decrease in the number of students from year to year. The level of public trust in sending their children to Muhammadiyah primary schools is still low. It is known from the number of ABA Kindergarten alumni, there is no $50 \%$ who continue to the Muhammadiyah elementary school level. The problem in this study is the decline in the number of new students and the decline in public interest in sending to Muhammadiyah elementary schools.

Efforts have been made by the school so far with various efforts including promotion through social media, procuring various kinds of creative activities, giving uniforms, and scholarships. These efforts have not been successful in comparison with the competition by high paying public primary schools and private schools. This requires a breakthrough to increase the interest of new students and a sense of public trust through the marketing mix. This relates to four things including products produced by schools to community satisfaction, prices offered 
by schools, promotions distributed by schools, and affordability of access to school premises. These four components are contained in the marketing mix.

Kotler and Armstrong [2] state that marketing is the process of creating value for customers in building strong relationships with customers with the aim of knowing the value of the customer in return. Marketing means obtaining customer satisfaction with the services provided by the school to parents of students in fulfilling their needs. Marketing activities include drafting concepts or characteristics of schools, determining price withdrawals, school promotion, and distribution of a number of ideas that are reflected in every school activity, products that are superior to schools, and optimal services. Kotler and Armstrong [2] state that the marketing mix is a set of controllable tactical marketing tools that a company combines to produce the response it wants in the target market. The marketing mix includes items of marketing tools, namely product, price, promotion, and place (4P). The product consists of product variety, quality, design, features, brand name, and packaging. The price consist of list price, discount, allowances, and payment period. The promotion consist of advertising, sales promotion, public relation, personal selling, and direct marketing. The place consist of coverage, assortments, locations, inventory, transportation, and channels.

The community in this case as consumers or service users. Kotler [1] the position of society as a decision maker and determinant of satisfaction. purchasing decisions is a conscious process that has been wise in choosing or buying. Kotler and Keller [3] state that the factors that influence purchases include cultural, social, personal, and psychological. Culture is related to people's beliefs, in this case taking sides in practicing religion. The community in Purworejo generally sided with the nahdatul ulama group, so that the community was fanatical when there were other groups. Social is related to the composition of society. Every Muhammadiyah school in Purworejo has different social conditions. Social in this case relates to work, income, level of crowd, perspective, and language of communication. Personal relates to choices that are tailored to each other's financial circumstances, the choice to provide the best for the child, and the level of activity. Psychologically related to the comfort and confidence of a person in a school institution. The opinion in the community that schools in Muhammadiyah are less qualified schools. So they hesitate to send to Muhammadiyah schools.

The purpose of this research is to find out what attracts the parents of students in sending their children to Muhammadiyah elementary schools. This attraction will later become a promotional force for schools to maximize the acceptance of new students and increase the sense of public trust. This research procedure uses a survey method of eight Muhammadiyah elementary schools in Purworejo.

\section{Method}

This research uses a qualitative type with a survey method. This type of qualitative research used in this study aims to acknowledge whether there is an influence between the independent variable and the dependent variable. The survey design in this study was used to obtain primary data by filling out a questionnaire containing statements to respondents. Data collection techniques in this study used interview techniques, questionnaire techniques, surveys, and documentation studies.

The population in this study all parents of students who send their children to eight levels of Muhammadiyah elementary schools in Purworejo as many as 8 elementary schools became the population in this study. The sample in this study included the total number of students in 
the 2019/2020 school year at the Muhammadiyah elementary school level in Purworejo totaling 100 respondents, with an explanation research sample distribution in the Table 1.

Table 1. Research Sample Distribution

\begin{tabular}{llll}
\hline Number & School Name & Population Size & Number of Respondents \\
\hline 1 & MI Krendetan & 30 & 8 \\
2 & SDM Kutoarjo & 120 & 34 \\
3 & SDM Bruno & 10 & 3 \\
4 & SDM Kemiri & 42 & 12 \\
5 & SDM Purworejo & 35 & 10 \\
6 & SDM Jono & 56 & 16 \\
7 & SDM Purwodadi & 52 & 15 \\
8 & SD KUB & 12 & 3 \\
\hline & Amount & 357 & 100 \\
\hline
\end{tabular}

The data collection method used in this study using a questionnaire. Data collection was carried out by distributing questionnaires directly to respondents. Respondents' answers were assessed using a Likert scale consisting of five choices including SS (strongly agree) $=5, \mathrm{~S}$ $($ agree $)=4, \mathrm{~N}($ neutral $)=3$, TS $($ disagree $)=2$, STS $($ strongly disagree $)=1$. instrument test using validity test and reliability test. The validity test to measure the validity of the questionnaire given to respondents is done by comparing the Cronbach Alpha value in the Corelated ItemTotal column. Reliability test by measuring the reliability of a variable by looking at Cronbach Alpha with a significance used more than 0.70 .

\section{Results and Discussion}

\subsection{Research Results}

The results of the multiple linear regression analysis partially show that the product, with a sig. $0.006(<0.05)$ means that it is influential. So the product will affect the purchase decision. The effect, when viewed from the standard value of the beta coefficient is 0.318 and is positive, meaning that the better the product, the greater the purchase decision. Price, with a sig. 0.002 $(<0.05)$ means that it is influential. So the price will affect the purchase decision. The effect, when viewed from the value of the beta coefficient is 0.336 and is positive, meaning that the more the price rises, the greater the purchasing decision. Promotion, with sig. $0.185(>0.05)$ means no effect. Promotion variable has no effect on purchasing decisions. Place, with a sig. 0.426 (> 0.05) means no effect. The place variable has no effect on purchasing decisions.

The results of partial multiple linear regression analysis in the Table 2 and the results of multiple linear regression analysis simultaneously in the Table 3. Based on the Table 2 and 3, it can be explained that simultaneously or together, this marketing mix variable has a positive effect on purchasing decisions. This is indicated by the sig value of $0.000(<0.05)$ and $\mathrm{F}$ which is positive. 
Table 2. Results of Partial Multiple Linear Regression Analysis

\begin{tabular}{|c|c|c|c|c|c|c|}
\hline \multirow{2}{*}{\multicolumn{2}{|c|}{ Model }} & \multicolumn{2}{|c|}{ Unstandardized Coefficients } & \multirow{2}{*}{$\begin{array}{c}\begin{array}{c}\text { Standardized } \\
\text { Coefficients }\end{array} \\
\text { Beta } \\
\end{array}$} & \multirow[b]{2}{*}{$t$} & \multirow[b]{2}{*}{ Siq. } \\
\hline & & B & Std. Error & & & \\
\hline \multirow[t]{5}{*}{1} & (Constant) & .355 & .222 & & 1.598 & .113 \\
\hline & Produk & .386 & .137 & .318 & 2.824 & .006 \\
\hline & Harga & .346 & .108 & .336 & 3.204 & .002 \\
\hline & Promosi & -.142 & .106 & -.128 & -1.336 & .185 \\
\hline & Tempat & .056 & .070 & .079 & .799 & .426 \\
\hline
\end{tabular}

a. Dependent Variable: Keputusan_Pembelian

Table 3. Results of Multiple Linear Regression Analysis Simultaneously

\begin{tabular}{|ll|r|r|r|r|r|}
\hline Model & & \multicolumn{1}{c|}{$\begin{array}{c}\text { Sum of } \\
\text { Squares }\end{array}$} & \multicolumn{1}{c|}{ df } & Mean Square & F & Sig. \\
\hline 1 & Regression & 13.222 & 4 & 3.306 & 11.321 & $.000^{=}$ \\
& Residual & 27.738 & 95 & .292 & & \\
& Total & 40.960 & 99 & & & \\
\hline
\end{tabular}

a. Predictors: (Constant), Tempat, Harga, Promosi, Produk

b. Dependent variable: Keputusan_Pembelian

\subsection{Discussion}

The decrease in the number of new students based on the survey results was influenced by products and prices. The product in this case is the hallmark of the school and the excellence of the school. The effect of the product on the decrease in the number of new students is because the products produced or superior products are not in accordance with the wishes of prospective new students. Likewise in the case of services at schools not in accordance with the expectations of prospective new students. The number of Muhammadiyah elementary schools in Purworejo out of 8 schools that have repaired the product components are 2 including the Muhammadiyah elementary school Kutoarjo and the Purworejo Muhammadiyah elementary school. This was obtained from data on four new academic years starting from 2016/2017, 2017/2018, 2018/2019, 2019/2020. The following is an explanation data on new students in the last four years in the following image Figure 1.

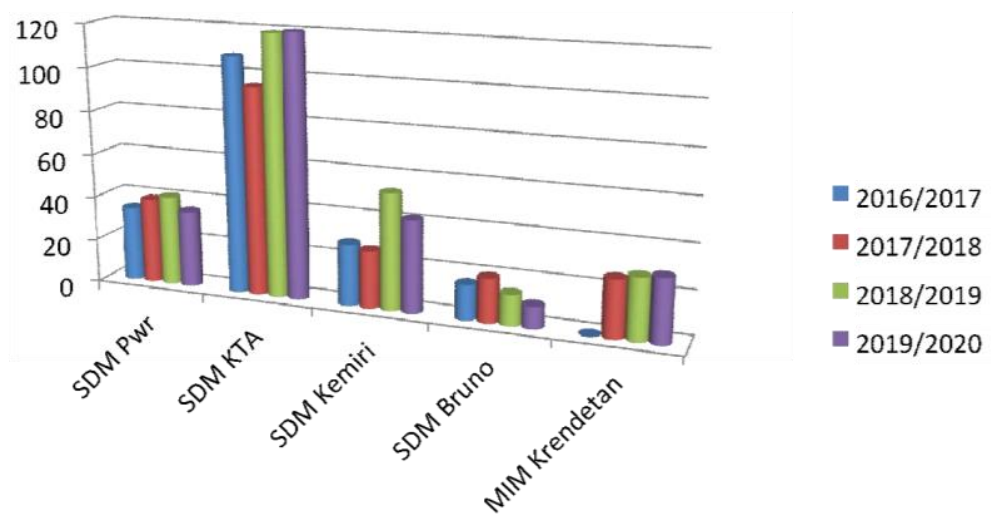

Fig. 1. Data on new students in the last four years 
The effect of price in reducing the number of new students in the form of funds set by the school is not in accordance with the economic conditions of prospective new students. There is little information about scholarships for prospective new students. So that there needs to be improvements in the product aspect or superiority of Muhammadiyah elementary schools to recruit new prospective students and price competition so that Muhammadiyah Elementary School remains the first choice for prospective new students.

Based on the results of a survey of 100 respondents, parents of students stated that $27 \%$ strongly agreed and $37 \%$ agreed with the availability of scholarships for high achievers and underprivileged people. Regarding the affordability of education costs, respondents responded that $6 \%$ strongly agreed and 55\% agreed. Thus, the decline in the number of new students from the price component was influenced by the availability of scholarships and the affordability of education costs.

The decline in public interest in sending Muhammadiyah elementary schools was influenced by products, prices, and the marketing mix. Product components that affect the attractiveness of society to send to Muhammadiyah primary schools include the quality of education in this case school institutions, school support programs, school services, and quality of graduates. The percentage of survey results regarding the quality of education of respondents stated that they strongly agree as much as $2 \%$ and 52\% agree that Muhammadiyah schools have criteria for good quality education. As a component of the existence of an attractive academic support program, respondents agreed as much as 56\% agreed that Muhammadiyah elementary schools offer parents of students several interesting academic support programs and optimize students' talents and potential. The aspects of service by teachers and employees of Muhammadiyah elementary schools are in satisfying stages. This is based on data from the survey results, 55\% expressed satisfaction with the services provided by Muhammadiyah elementary school teachers and employees. The community views the quality of graduates as important in reflecting the quality of schools. The results of the survey stated that $24 \%$ of respondents said Muhammadiyah primary school graduates could compete with other primary school graduates.

The price component that affects the attractiveness of the community to attend Muhammadiyah elementary schools includes the cost of education and the availability of scholarships. What is crucial and sensitive for the community is the issue of financing, so that people often compare financing between one school and another. The results of a survey of 100 respondents regarding affordable school funding, sources of financing information from brochures/ banners/pamphlets, and the availability of scholarships. As many as $6 \%$ disagree and $55 \%$ disagree that school financing should be affordable by parents. This is because the operational funding for Muhammadiyah schools is independent. Based on financing information sources, $24 \%$ expressed disagreement, because financing information sources were faster to obtain orally. The availability of scholarships for the community is very important. This is to encourage students to excel. that $27 \%$ disagree and $37 \%$ disagree. This is because the scholarships available are institution-bound.

Marketing mix consisting of product, price, promotion, and place. Products consist of services, academic support programs, quality of education, and quality of graduates. The price consists of tuition fees and scholarships. Promotion consists of direct communication, advertisements, program promotions, and the physical appearance of the school. The place consists of strategic, easy to reach public transportation, parking space, and a comfortable environment. The four components in the marketing mix will influence people's decisions and satisfaction as users. buyer's decision consists of steadfastness and providing recommendations to others. Buyer satisfaction consists of feeling happy and proud, recommendations for oneself 
and others, activeness in extracurricular activities, satisfaction with the programs offered by the school, service satisfaction, and satisfaction with the quality of education.

\section{Conclusion}

The components in the marketing mix from previous studies have had a positive effect. This is evident from Irawan and Khasanah's research with the following explanation. Irawan's[4] research results regarding the marketing mix of service marketing and the decision of parents in choosing a school state that the statistical test results show that the service marketing mix jointly influences the decision to choose a school. This is evident from the variable product, price, place, promotion, people, physical evidence, and process partially have a significant effect on the decision to choose a school, while the price and place variables partially do not have a significant effect on the decision to choose a school. Among these variables, the promotion variable is the most dominant variable affecting the decision to choose a school. Khasanah[5] in research using a marketing mix consisting of 7P, namely product, price, place, promotion, people, physical evidence, and process. The seven marketing mixes are identified as strategic steps in marketing educational services which include Market Identification, Market Segmentation and Positioning, Product Differentiation, and School Services.

Products have a positive effect on purchasing decisions. In this research, the product means all the facilities offered by the school for the service of teachers and employees, support programs, to the profile of existing graduates. The purchasing decision, in this case the parents of students willing to send their children to Muhamamdiyah schools, is very dependent on the product. This physical picture of the school, school facilities and the output of students who graduate is the most attractive thing for parents. In interviews with students, it was found that if they went to school, they did not only want their children to excel in academics, but could memorize a number of juz, have Islamic habits such as praying dhuha, reading the Koran and good manners.

Price has a positive effect on purchasing decisions. In this study, the price is reflected by the tuition fees that parents must pay to school. However, there are also scholarships that are possible for students who excel or are less well off. Several Muhammadiyah schools set tuition fees to be quite cheap and affordable. The number of scholarships ranging from organizational scholarships, BOS scholarships or others makes it attractive for parents of students to send their children there. There is even a Muhammadiyah SD which makes education free.

Promotion has no effect on purchasing decisions. In this case, the promotion is carried out by the institution through brochures and events. So far, the promotion carried out by Muhamamdiyah schools has not had an effect, meaning that it has not been able to influence the parents of students to send their children to Muhamamdiyah schools. Schools are considered to still carry out promotions in a standard manner and are far from attractive, even in some Muhammadiyah schools there are no brochures and promotions are only done by word of mouth.

Place has no effect on purchasing decisions. The place in question is the ease of transport, location, parking facilities and convenience of the place. Purchasing decisions are not affected by the venue. This means that the superiority of location cannot be utilized by the school to attract parents' interest in sending their children to school. Therefore, products have a positive effect on purchasing decisions, price has a positive effect on purchasing decisions, promotion has no effect on purchasing decisions, and place has no effect on purchasing decisions. 


\section{Acknowledgment}

This research was conducted as a form of the tri darma of higher education which is included in the national research grant competency. This research was carried out thanks to the support of the regional leadership of Muhammadiyah Purworejo who had permitted them to conduct research. We would like to thank all Muhammadiyah elementary school principals who have been willing to be research targets. We also thank respondents who have been willing to be involved in the research. The entire survey team who spent their energy and time to participate in the success of this research.

\section{References}

[1] Kotler, P., Manajemen Pemasaran Indonesia Edisi Pertama, Jakarta: Salemba Empat, 2001.

[2] Kotler, P. and Amstrong, G., Prinsip-prinsip Pemasaran, Jilid 1 Edisi Kedua Belas, Jakarta: Erlangga, 2008.

[3] Kottler, P. and Keller, K. L., Manajemen Pemasaran Jilid II Edisi Ketiga belas, Jakarta: Erlangga. 2012.

[4] Irawan, Immanuel C., Analisis pengaruh bauran pemasaran jasa terhadap keputusan wali murid memilih sekolah dasar, Journal of Business and Banking, Vol. 7 No. 2, page 263-276, November 2017.

[5] Khasanah, A., Pemasaran Jasa Pendidikan sebagai Strategi Peningkatan Mutu di SD Alam Baturraden, Jurnal eL-Tarbawi, Volume VIII No.2, Page 161-176, Agustus 2015. 